\title{
Studying of Cutting Zone When Finishing Titanium Alloy by Application of Multifunction Measuring System
}

Andrej Czán, Michal Sajgalík, Jozef Holubjak, Karel Kouril

University of Zilina, Faculty of Mechanical Engineering, Univerzitná 1, 010 26, Žilina Slovakia, Slovak Republic, andrej.czan@fstroj.uniza.sk

With the development of the automotive and aerospace industry and also biomedicine, exotic alloys are more and more used from all machined materials, especially titanium and nickel alloys, but which are hard-machined materials. Therefore it is necessary to know their behavior when machining, thoroughly. Processes occurring in the cutting zone when machining, are so complicated and dynamic, that their definition is carried out by certain specified models. Because the models have errors and deviations, it is needed to improve their observation so, that these deviations will manifest minimally or not. Based on the scientific research of the cutting zone, the multifunction measuring system was designed, which allows simultaneous measuring of components force of cutting, heat distribution and deformation processes in cutting zone during machining without its interruption.

Keywords: multifunction measuring system, cutting zone, high-speed movie, titanium alloys

\section{Acknowledgement}

The article was funded by funds of the project with the University of Zilina OPVaV-2009/2.2/04-SORO number (26220220101) - "Intelligent system for nondestructive technologies on evaluation for the functional properties of components of X-ray diffraction "and project VEGA 1/0773/12 Implementation of technical ceramic material research to increase the innovation of hybrid products

\section{References}

[1] CEP, R., KOURIL, K., MRKVICA, I., JANASEK, I., PROCHAZKA, J. (2010) Zkoušky nastroju Kyocera v podminkach prerusovaneho rezu. In. Strojirenska technologie, vol. XV, 2010/3, pp. 51-58, ISSN 1211-4162.

[2] CEP, R., JANASEK A., PETRU J., CEPOVA L., CZAN A., VALICEK J. (2013) Hard Machinable Machining of Cobalt-based Superalloy. In ManufacturingTechnology XIII/13 . UJEP: Ústi n. Labem. p. 226-231. ISSN 12132489

[3] BREZNIČAN, M., FABIAN, P., MESKO, J., DRBUL, M., (2013) The Simulation of Influence of Quenching Temperature on Properties of Bearing Rings. In ManufacturingTechnology XIII/13 . UJEP: Ústi n. Labem. p. 2025. ISSN 1213-2489

[4] CZAN, A. , TILlOVA, E., SEMCER, J., PILC, J. (2013) Surface and subsurface residual stresses after machining and their analysis by x-ray diffraction. In. Komunikacie, Volume 15, Issue 2, 2013, Pages 69-76. ISSN 1335-4205

[5] HOLESOVSKY, F., NAPRSTKOVA, N., NOVAK, M., (2009) GICS for grinding process optimization. In ManufacturingTechnology XII/12. 2012. UJEP: Ústi n. Labem. p. 22-26. ISSN 1213-2489.

[6] LUKOVICS, I., BILEK, O., HOLEMY, S. (2010) Aplikace sintrovaneho korundu ve vyrobe naradi. In. Strojirenska technologie XV - 2010/3, s - 27-34, ISSN 1211-4162.

[7] NOVAKOVA, J., PETRKOVSKA, L., BRYCHTA, J., STANCEKOVA, D. (2009). Influence of Cutting Parameters On Integrity Surface At High Speed Cuttin. Transactions of the VŠB - Technical University of Ostrava. Mechanical Series, ročník LV., číslo 1/2009, Česká republika. Ostrava: VŠB - TUO, pp. 203-209

[8] PILC, J.- VASILKO, K. (2013) Development and applications of a rotating turning tool. In ManufacturingTechnology XIII/13 . UJEP: Ústi n. Labem. p. 226-231.

[9] SAJGALIK M., CZAN A., (2011) Studying of processes in cutting zone by non-destructive methods, volume 8, number 2 of Technological Engineering, University of Zilina in Zilina.

[10] SAJGALIK M., STANCEKOVA D., JURKY M., KURNAVA P. (2012) Application of thermovision systems and highspeed scanning for monitoring of dynamic processes in the cutting zone in turning of superalloys, volume 6 of Advanced manufacturing technologies

[11] MRKVICA, I., JANOŠ, M., SYSEL, P. (2012) Contribution to milling of materials on Ni base. In Applied Mechanics and Materials 217-219, pp. 2056-2059. ISSN: 1660-9336

[12] WHITENTON E.P., IVESTER R., et al. (2005) Simultaneous visible and thermal imaging of metals during machining in Thermosense XXVII. Orlando, International Society for Optical Engineering.

[13] WHITENTON, E.P. (2010) High-speed dual spectrum imaging for the measurement of metal cutting temperatures, Manufacturing Engineering Laboratory, NIST, Gaithersburg 
[14] CEP, R., JANASEK, A., CEPOVA, L., PETRU, J., HLAVATY, I., CAR, Z., HATALA, M. (2013) Eksperimentalno ispitivanje rezne sposobnosti izmjenjivih reznih umetaka | [Experimental testing of exchangeable cutting inserts cutting ability]. In Tehnicki Vjesnik 20 (1) , pp. 21-26. ISSN: 1330-3651

[15] MOHYLA, P., TOMCIK, P., BENES, L., HLAVATY, I. (2011)Effect of post-welding heat treatment on secondary hardening of welded joints of Cr-Mo-v steel. Metal Science and Heat Treatment 53 (7-8), pp. 374-378. ISSN: 0026-0673. 